scholarship on biblical plays, which places her study with works by David Bevington (Tudor Drama and Politics), Greg Walker (Plays of Persuasion, Reading Literature Historically), and Paul Whitfield White (Theatre and Reformation). Her study is beneficial to readers interested in literature, religion, and the cultural context of biblical plays. It is also helpful in demonstrating the link between different genres of text from different religious traditions.

NILAB FEROZAN

McMaster University

\title{
Greenblatt, Stephen.
}

Marvelous Possessions: The Wonder of the New World. With a New Preface. Chicago: University of Chicago Press, 2017. Pp. xiv, $202+10$ ill. ISBN 978-0226-52504-5 (paperback) US $\$ 22.50$.

Stephen Greenblatt produced three adept and influential books in just over a decade: Renaissance Self-Fashioning (1980), Shakespearean Negotiations (1988), and Marvelous Possessions (1991), whose re-edition of 2017 I am reviewing here. Over the years, I have either made use of Greenblatt's work in my own scholarship or reviewed his work and books on new historicism, or that "school" itself, sometimes by itself or in relation to cultural materialism, a related movement or endeavour that was associated most with Jonathan Dollimore and Alan Sinfield. While my own work differs from Greenblatt's, I admire him. His work and the wider approaches of new historicism and cultural materialism have made Renaissance studies, cultural studies, and literary studies more interesting. As a writer, literary scholar, and historian, I have found the world much the richer for the work of Greenblatt and others on both sides of the Atlantic, and later globally, who have engaged with text and context in a way that takes history into account.

Greenblatt himself has a nimble mind, bringing wonder to his readers as he fashions himself and negotiates with Shakespeare, the Renaissance, and the New World. He is a fine stylist and writer as well as a bold thinker and teacher. His talks are as marvellous as his books. Greenblatt is what a humanist scholar should be and gives the lie to anyone who would discount literature, history, or the humanities as being unimportant in university or society at large. Arts, 
along with theology, medicine, and law, were the foundation of the European university, seen most clearly in the early years of the University of Paris. One can imagine that Greenblatt would have been a marvellous scholar and teacher in any age of the university. Berkeley and Harvard were wise enough to know that; we, as colleagues and readers, are fortunate to overhear Greenblatt and to engage with him in the drama of meaning in his books.

After noting some of the contributions of Marvelous Possessions, I shall concentrate on the new preface to this new edition. The book itself was part of the volumes produced in the years surrounding 1992, the quincentennial of Columbus's landfall in the Caribbean or New World, and it concentrates on the meetings and cultural encounters of the European invaders and newcomers and the Native peoples. It examines the marvellous or sense of wonder in European representations of, and responses to, the New World.

Greenblatt's book, although a fine work of style and substance in scholarship, is also personal. The acknowledgements begin with a claim that this study of travel writing owes its existence to "exotic realms" beyond California (xii). Greenblatt says that Zionism and the Dome of the Rock also bring pressure to a book about other times and places, and he formulates the central question of the volume: "how is it possible, in a time of disorientation, hatred of the other, and possessiveness, to keep the capacity for wonder from being poisoned?" (xiv; see also xiii). The introduction begins with Greenblatt's favourite books as a child, The Arabian Nights and Richard Halliburton's Book of Marvels, and these set the scene for his own book. Greenblatt weaves his own travel anecdotes with those he explores-for instance, a trip to Bali in 1986and he alludes to Clifford Geertz, Margaret Mead, and other experts on Bali, for like them (and Anthony Pagden [3]), Greenblatt is interested in ethnology. He focuses most on the representational practices of the Europeans in the Americas (7), with an emphasis on writing, translation, communication, otherness, and wonder (8-25). For Greenblatt, there is a typology of then and now, here and there, so he wanders in wonder between present and past, New World and Old World, old and new Jerusalem. Chapter 2 examines John Mandeville in whom the language of the marvellous occurs through renunciation (26-51). Mandeville's acceptance of others does not apply to the Jews who are rivals for the Holy Land and the world (49-50). Chapter 3 analyzes Columbus's language of the marvellous in terms of his making aesthetic and redemptive a legal ritual 
of appropriation (52-85). Greenblatt maintains that for a moment, one "of perfect wonder and of possessive madness-Columbus has become the king of the Promised Land" (85). Chapter 4 is about the kidnapping of language, including Columbus's practice, but also kidnapping as part of a ruthless trade as exemplified by the forcible abduction of an Inuit during Martin Frobisher's expedition, as reported by George Best, and the bringing back of fool's gold (86-118). Greenblatt moves from medieval wonder as dispossession to Renaissance wonder as appropriation. Chapter 5-on go-betweens-ends the book with possibility, as seen through an analysis of Herodotus, Bernal Díaz, and Michel de Montaigne in which the eyewitness, which includes Greenblatt and us, recognizes the marvellous and the surprise of the self in the other and the other in the self: the utopian moment of travel elsewhere to find wonder at home (119-51). That chapter concludes with an anecdote of Greenblatt's visit to the village of Tlacochahuaya, in the valley of Oaxaca, associated with Hernán Cortés and where Greenblatt sees the Mixtec god of death looking down at the dead Jesus (150-51). The book begins and ends with religious signs, a marvel and a wonder that are also displaced into the secular.

Greenblatt's "Preface: Plunder and Wonder" provides a retrospective reading or interpretation of this book that is helpful and perceptive and not an ex post facto rationalization. He says the book is about an "extraordinary crosscultural encounter" and focuses on "an intense wonder," which the parties to this encounter shared, a wonder before comprehension (v). This "foundational experience" of wonder might help to explain the why of the events and the how of the actors representing to themselves what they were doing (vi).

Greenblatt uses films from silent movies of 1916 and 1923 about Columbus to later films on exploration like Cabeza de Vaca (1991) to explain the sense of wonder, but also calls on science fiction films such as Close Encounters of the Third Kind (1977) and Arrival (2016) to cast light on cultural encounter, wonder, and kidnapping, so central to Marvelous Possessions (vi-vii). Moreover, in these terms, he discusses H. G. Wells's novel War of the Worlds (1897), and Steven Spielberg's film version of it (2005) as well as the Independence Day films (vi-viii). Greenblatt also mentions the critique of the encounter in Las Casas, Montaigne, and Swift but sees Mandeville, the "knight of non-possession," as "the ethical hero of my book" (ix). Greenblatt uses Mandeville to disrupt the connection between plunder and wonder because the marvellous can show 
what eludes us and what we cannot possess. Mandeville's wonder is tolerance, but Columbus's is unsatiated appetite (ix).

For Greenblatt, central to the whole cultural encounter of Europe with the New World is the role of go-betweens, like Doña Marina and Aguilar, as Bernal Díaz describes in the narrative of the encounter between Moctezuma and Cortés, as part of "the great representation machine" as Greenblatt calls it (x). These go-betweens also help to represent all the emotions of such an encounter-including wonder ( $\mathrm{x}-\mathrm{xi})$.

Greenblatt says "Much of my book centers on the way in which wonder was yoked to possession" but he also sees the possibility of wonder beyond appetite, something glimpsed at in Herodotus, Mandeville, and Montaigne: "the dream of gift-giving, the thrilling apprehension of ways of being other than one's own, the intimation of brotherhood" (xi). Greenblatt ends his preface with an admission that Marvelous Possessions tells a tragic story but returns over and over to aspects of life beyond despair: "curiosity, magnanimity, generosity, selfcriticism, the will to experiment, the dream of justice" (xi). Stephen Greenblatt's book contributes to our wonder and is a gift that keeps on giving in an attempt to understand possession but also to get beyond it.

JONATHAN LOCKE HART

Shanghai Jiao Tong University

\section{Gusmão, Alexandre de.}

The Story of the Predestined Pilgrim and His Brother Reprobate in Which, Through a Mysterious Parable, is Told the Felicitous Success of the One Saved and the Unfortunate Lot of the One Condemned. Trans. with intro. and index by Christopher C. Lund.

Medieval and Renaissance Texts and Studies 489 / Medieval and Renaissance Latin America 2. Tempe: Arizona Center for Medieval and Renaissance Studies, 2016. Pp. xxxv, $137+9$ b/w ill. ISBN 978-0-86698-544-4 (hardcover) US $\$ 55$.

The Story of the Predestined Pilgrim and His Brother Reprobate is a narrative of two brothers' journeys from Egypt. This "allegorical novel of salvation" was written by the Jesuit priest Father Alexandre de Gusmão in Brazil, and was first published in 1682. On the "surface" a usual journey, it is narrated by Gusmão as 